\title{
Egg proteomic characterization of Seriola rivoliana in captivity
}

\author{
Vania Serrano-Pinto ${ }^{1}$, Benoit Bernay ${ }^{2}$, Manuel Moreno-Legorreta ${ }^{1}$ \\ Alfredo Ortega-Rubio ${ }^{1}$ \& Minerva Maldonado-García ${ }^{1}$ \\ ${ }^{1}$ Centro de Investigaciones Biológicas del Noroeste, La Paz, BCS, México \\ ${ }^{2}$ Plateforme Proteogen, SFR ICORE 4206, Université de Caen Basse-Normandie \\ Caen, France \\ Corresponding author: Vania Serrano-Pinto (vserrano04@ cibnor.mx)
}

\begin{abstract}
Continuous and sustained production of good quality eggs and larvae is required to have economically viable and ecologically sustainable rearing of Seriola rivoliana. Nonetheless, the complete production cycle of these species has been challenging to achieve due to high mortality during embryonic and larval stages. The objective of the project was to study the expression of the proteins involved in the embryonic process of almaco jack. Proteomic characterization of fertilized eggs was performed using two-dimensional electrophoresis and mass spectrometry. Different vitellogenin proteins $\mathrm{A}, \mathrm{B}, \mathrm{C}$ and $\mathrm{Ab}, \beta$-actin, peroxiredoxin, superoxide dismutase 1, alpha subunit proteasome, and keratin II were identified to their functions related to embryonic development, energy metabolism, protein synthesis, cell structure, cytoskeleton, and antioxidant proteins with defense enzymatic activity.
\end{abstract}

Keywords: Seriola rivoliana; fish eggs proteomics; two-dimensional electrophoresis; mass spectrophotometry; proteomic biomarkers; oxidative stress

The longfin yellowtail almaco jack (Seriola rivoliana, Carangidae) is a neritic and oceanic pelagic fish of wide distribution with significantly valuable fishery and aquaculture activities in Mexico. Artificial rearing of this species is required to become an economically viable and ecologically sustainable activity. Thus, constant and sustained production of good quality eggs and larvae should be performed under controlled conditions (Carnevali et al., 2001). Nevertheless, the complete reproduction cycle of almaco jack has been challenging to achieve due to the high mortality during embryonic and larval stages (Palomino et al., 2017) partly due to a lack of information on egg composition and physiology. The egg needs all the essential biochemical components to develop a viable embryo; these materials are obtained from the nutrients transferred by the females during oocyte growth within the ovary (Sullivan et al., 2015). The quality of fish eggs and larvae is variable; many of the factors that affect quality are still unknown, but spawning egg quality of animals in captivity is usually lower than that of organisms recently caught from the wild (Carnevali et al., 2001). In the aquaculture industry "good egg qua- lity" has included some quantitative aspects, such as the fertilization capacity of the sperm and competence of the eggs to be fertilized, morphological characteristics, biochemical content, and hatching rates (Kjørsvik et al., 1990; Bromage et al., 1994). Various morphological and physiological characteristics have also been taken into account as quality indicators of fish gametes. Some authors have suggested that the shape of the egg, its transparency and distribution of the oil drops, and egg buoyancy are used as good quality markers in marine fish hatcheries (Kjørsvik et al., 1990; Carnevali et al., 2001). Spherical and highly ellipsoidal lipid droplets have been reported to be indicators of low embryonic survival and egg quality, while eggs with slightly ellipsoidal lipid droplets indicate high embryonic survival (Lahnsteiner et al., 2008). A series of parameters that directly or indirectly influence egg quality have been identified from induction mechanism to spawning; for example, physical and chemical factors, such as photothermal manipulation, oxygen concentration and salinity (Heming \& Buddington, 1988), hormonal injection (Bromage et al., 2001). Important factors to consider are the broodstock nutri-

Corresponding editor: Patricio Dantagnan 
tional quality, eggs incubation conditions, or breeders' physiological state, hatching rate, and survival at first artificial feeding (Sullivan et al., 2015). Also, important would have a higher quality egg in species with controlled reproductive cycles already closed in captivity since the feeding of the parents guarantees good nutritional quality, and consequently, a better nutritional reserve would be expected in eggs (Lahnsteiner et al., 2008; Roo et al., 2014).

The different stages of fish oocyte development are associated with changes in protein composition necessary for their proper development; some of these proteins are stored to be used during fertilization and later in embryonic development (Cerdà et al., 2007). The production of good quality fish eggs depends on different molecular processes; many of them are still unknown, so their knowledge is essential. Inadequate reproductive confinement and nutritional conditions may induce changes in the oocyte proteome and affect egg quality (Cerdà et al., 2007). For this reason, proteomic analyses of fertilized eggs can be instrumental in identifying proteins that are expressed or disappear during their development and could be used as quality biomarkers for fertilized eggs. The use of these technologies can discover new biological connections between proteins, genes, and metabolic pathways; thus, they can be potent tools for understanding the genetic and molecular basis of gamete (Cerdà et al., 2007) and fertilized egg formation. Different studies have addressed the proteomic aspect of fish reproduction (Olin \& Von Der Decken, 1990; Rime et al., 2004; Knoll-Gellida et al., 2006; Link et al., 2006; Tay et al., 2006; Ziv et al., 2008; Palmblad et al., 2013; Williams et al., 2014). However, very few have been available on proteomics and embryonic development of the genus Seriola. (Keyvanshokooh \& Vaziri, 2008; Roo et al., 2014; Palomino et al., 2017; Pousis et al., 2018), which is important information required to support decisionmaking by aquaculture producers on their rearing.

The longfin yellowtail broodstock of S. rivoliana was collected in the locality of Cabo San Lucas, Baja California Sur (BCS), Mexico, using a fishing rod with a hook, which was transported in a $700 \mathrm{~L}$ container with supplemental oxygen, to avoid stress and suffering for the organisms. Broodstock was captured in the natural reproductive season, so that males and females were obtained at the same time as the capture, in the same courtship area; they were kept for two years in remaking through environmental stimulation. Breeders were maintained in captivity with a photoperiod of 12 $\mathrm{h}$ and $30 \mathrm{~min} /$ light and $11 \mathrm{~h}$ and $30 \mathrm{~min} /$ darkness, with closed flow and temperature of $25^{\circ} \mathrm{C}$ in $40 \mathrm{~m}^{3}$ tanks with recirculation systems, $25 \%$ daily water exchange, and supplementary aeration for two years (ViaderGuerrero, 2019) until they had matured at Kampachi Farms at the Centro de Investigaciones Biológicas del Noroeste (CIBNOR), La Paz, BCS, Mexico ( $24^{\circ} 08^{\prime} \mathrm{N}$, $\left.110^{\circ} 25^{\prime} \mathrm{W}\right)$. The organisms were fed with sardine $(50 \%)$, mackerel (30\%), and squid (20\%) daily to satiety (Viader-Guerrero, 2019). S. rivoliana showed rapid growth, reaching a maximum standard length of $160 \mathrm{~cm}$ and a maximum weight of $59 \mathrm{~kg}$ in the wild, growing $1 \mathrm{~kg}$ in weight per year (Gopalakrishnan, 1985). The broodstock was sexed with a cannula inserted into the genital pore, where the presence of hydrated oocytes identified the females. The males underwent an abdominal massage to identify the presence of semen, which did not determine its quality or density and the volume of the semen. Once identified, the fish were marked according to sex (ViaderGuerrero, 2019). The fertilized eggs were obtained from spontaneous spawning from a batch of $S$. rivoliana breeders (seven females average weight $=7.5$ $\pm 2.3 \mathrm{~kg}$ and length $=63.4 \pm 5.3 \mathrm{~cm}$; five males weight $=8.2 \pm 3.2 \mathrm{~kg}$ and length $=75.3 \pm 2.4 \mathrm{~cm}$ ). The eggs used were obtained from the laying's timing, so it was not necessary to use hormones or carry out artificial fertilization. The fertilized eggs fell by gravity into a $500 \mathrm{~L}$ egg collector with a $500 \mu \mathrm{m}$ retention mesh at the time of spawning. The egg's size and the lipid drop had a diameter of $1.0327 \pm 0.00255 \mathrm{~mm}$, showing a lipid drop of $0.2535 \pm 0.0008 \mathrm{~mm}$, at a spawning temperature of $25^{\circ} \mathrm{C}$ (Viader-Guerrero, 2019). The fertilized eggs were frozen at $-80^{\circ} \mathrm{C}$ for subsequent proteomic analysis. Egg samples were evaluated following the methodology used by Serrano-Pinto et al. (2010) to perform proteomic characterization. Homogenized mixtures $(100 \mu \mathrm{L})$ from samples of 100 eggs were run in five gels; the mixtures were prepared with phosphate saline buffer with $2-20 \mu \mathrm{g} \mathrm{mL} \mathrm{m}^{-1}$ protease cocktail inhibitors $0.1-0.5 \mathrm{mM}$ serine and cysteine protease inhibitors (TLCK). Lysis buffer (8 M urea, 4\% CHAPS, $2 \%$ formalin at $\mathrm{pH} 3-10$ ) was added. For isoelectric focusing, an aliquot of $350 \mu \mathrm{g}$ proteins was used with a rehydration buffer to provide a total volume of $250 \mu \mathrm{L}$ for each aliquot of $200 \mu \mathrm{L}$ rehydration buffers and supplied with $0.56 \mathrm{mg}$ dithiothreitol (DTT) and $1 \mu \mathrm{L}$ IPG buffer. The mixture was placed within the gel holder with the strip containing gel separators from $\mathrm{pH}$ 3-10 (Immobiline Dry Strip pH 3-10 NL, Amersham Biosciences (Buckinghamshire, UK). The first step was a $2 \mathrm{~h}$ rehydration time only with the rehydration buffer. The first dimension of the isoelectric focusing system was run for a rehydration time of $16 \mathrm{~h}$ with a continuous current of $50 \mathrm{~mA}$ for the strip with a program: $1-100 \mathrm{~V}$ $\mathrm{h}^{-2}, 2-500 \mathrm{~V} \mathrm{~h}^{-1}, 3-1,000 \mathrm{~V} \mathrm{~h}^{-1}, 4-8000 \mathrm{~V} \mathrm{~h}^{-2.5}, 5-8000$ $\mathrm{V} \mathrm{h}^{-3.5}$. Two-dimensional electrophoresis (2-DE) was used to reveal soluble proteins in relatively high 
abundance and a specific $\mathrm{pH}$ range (3-10), isoelectric point (Ip) from 4.5-8.5, and molecular weight (Mw) from 17.5-76 $\mathrm{kDa}$ (Biorad, CA, USA). The gels were balanced in a buffer (Merck KGaA, Darmstadt, DE) with $50 \mathrm{mg} 5 \mathrm{~mL}^{-1}$ DTT and $125 \mathrm{mg} 5 \mathrm{~mL}^{-1}$ iodoacetamide. Fish eggs were analyzed by $2-\mathrm{DE}$ (OwlP9DS vertical gel system, Thermo Fisher Scientific, Waltham, MA) that separated proteins based on their molecular weight on $12 \%$ polyacrylamide gel SDS-PAGE at $100 \mathrm{~V}$ for eight hours. Gels were soaked for three hours, pre-incubated, and then dyed with 0.35 $\mathrm{g} \mathrm{L} \mathrm{L}^{-1}$ Coomassie brilliant blue G-250 with gentle agitation at room temperature for five days. The gels were scanned with Imagescanner III (Amersham Biosciences, Buckinghamshire, UK), and a bioinformatics program (Image Master 2D Platinum v7.0, Amersham Biosciences, Buckinghamshire, UK) was used to detect the number of spots or protein stains in each gel. The spots selected based on their higher spot volume expression were excised, washed, and faded. The tandem time-of-flight (TOF/TOF) mass spectrometry analysis was performed on an $\mathrm{AB}$ Sciex 5800 proteomics analyzer equipped with TOF TOF ion optics (Ontario, CAN) and an OptiBeam ${ }^{\mathrm{TM}}$ on-axis laser irradiation with $1000 \mathrm{~Hz}$ repetition rate (Applied Biosystems, CA, USA). Two-protein databases were used, an updated compilation of the Swiss-Prot database (including 552,259 entries) with Metazoa as selected taxonomy and a database downloaded from NCBI using Seriola as the selected genus (including 41530 entries) (NCBI, 2017). Mascot data were then transferred to an in-house developed validation software for data filtering according to a significance threshold of $<0.05$ and the elimination of protein redundancy based on proteins evidenced by the same set or a subset of peptides. Each peptide sequence was checked manually to confirm or contradict the Mascot assignment.

This study analyzed the proteomics characterization of $S$. rivoliana eggs, describing proteins during the embryogenesis process in captivity. To our knowledge, it is the first proteomic evaluation performed in this fish genus. Using the Image Master 2D Platinum program, some proteins (spots) were obtained, which showed approximately 200 well-resolved Coomassie-stained spots (Fig. 1). The molecular weight of these spots varied from 5 to $140 \mathrm{kDa}$, and 3-10 of isoelectric point $(\mathrm{pH})$ has been detected; 20 protein spots differentially expressed were identified (Fig. 1). The molecular weight of these spots varied from 15.8-131 $\mathrm{kDa}$, with an Ip range from 3-8.

Table 1 shows the characteristics of each spot after the MS/TOF TOF analysis, previously indicated in Figure 1. The spots analyzed were identified as sequence fragments of four vitellogenin (Vtg): A, B, C,

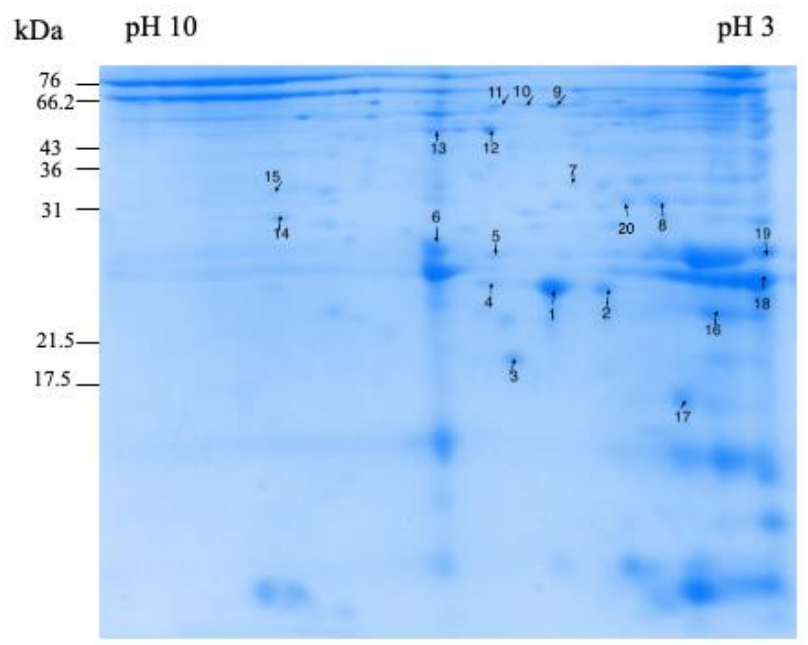

Figure 1. Display of two-dimensional electrophoresis of the full array of protein profile of Seriola rivoliana eggs.

and $\mathrm{Ab}$. Five additional proteins were also identified as $\beta$-actin, peroxiredoxin, superoxide dismutase 1, proteasome sub-unit alpha, keratin II. According to their function, the proteins identified were related to embryonic development, enzymatic activityproteolysis, enzymatic activity defense, cytoskeletal, and cell structure.

Among the proteins identified, five were expressed as multiple spots in different locations on the 2-DE map based on the peptide sequences, demonstrating that they were considered isoforms of the same protein (Table 1). These isoforms may be the result of posttranslational modifications, such as phosphorylation or glycosylation (Jensen, 2004, 2006). Examples of these proteins are $\mathrm{Vtg} \mathrm{B}, \mathrm{C}, \mathrm{Ab}, \mathrm{SOD} 1$, and $\beta$-actin.

In aquatic organisms, synthesis and degradation processes of Vtg (glycolipophospho protein precursors to yolk in egg-laying oviparous organisms) (Byrne et al., 1989; Serrano-Pinto et al., 2003) are important in oogenesis and embryogenesis processes. They provide essential nutrients, such as amino acids, lipids, carbohydrates, phosphates, and metal ions to the embryo (Fagotto, 1995). The Vtg sequences found in this study had homology with those of $S$. lalandi (Palomino et al., 2017) and S. dumerili (Pousis et al., 2018) (Table 1).

Another protein identified represented by three spots was a $\beta$-actin enzyme. Studies carried out on the Danio rerio embryo (Ziv et al., 2008) mentioned that the $\beta$-actin gene played a central role in structuring the cellular cytoskeleton. The embryo was subjected to a high cell proliferation rate; therefore, the $\beta$-actin gene was likely not to be expressed at the same level at different stages of embryo development. This protein had homology with the $\beta$ actin of $S$. quinqueradiata 


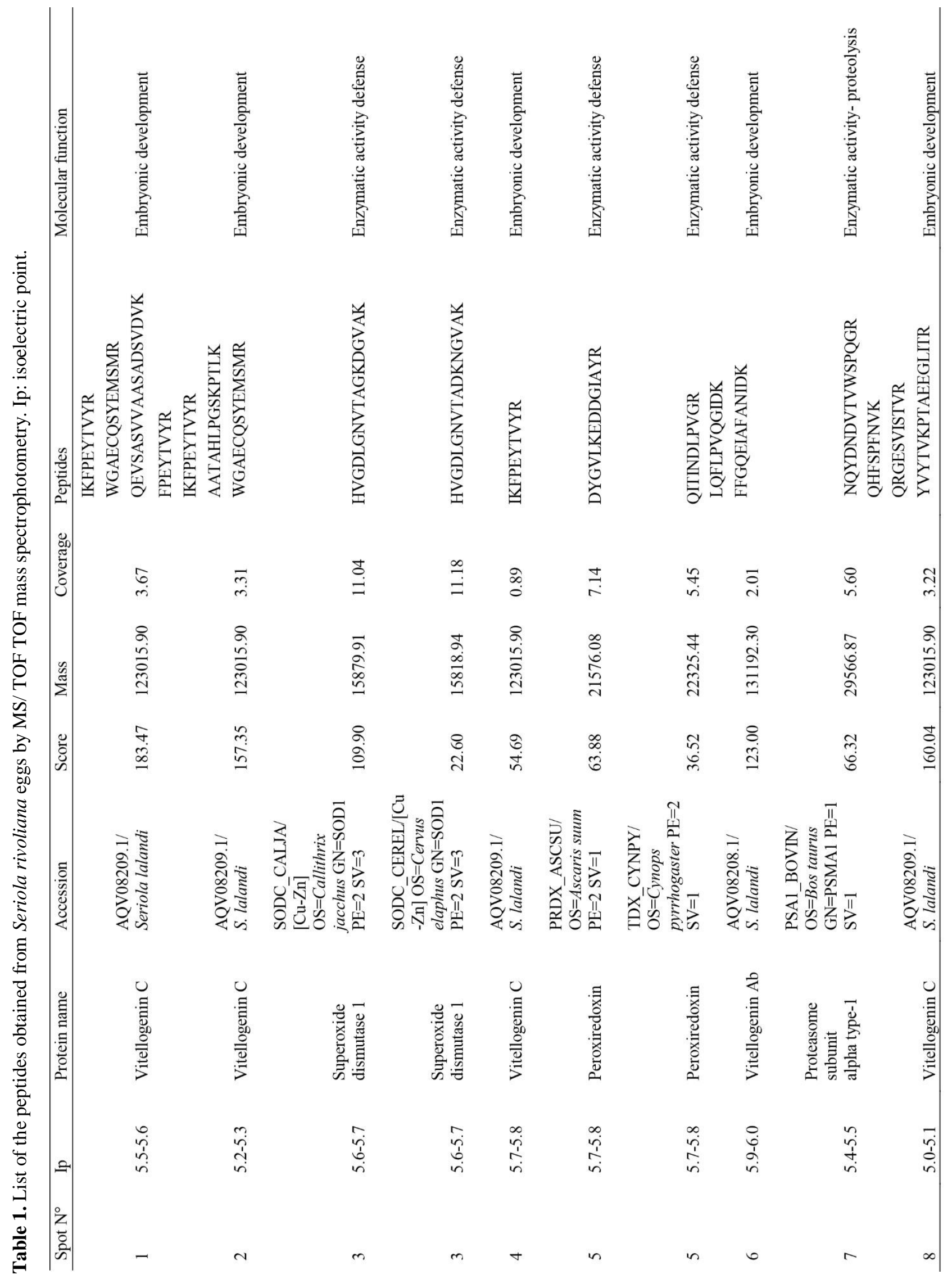


continuation

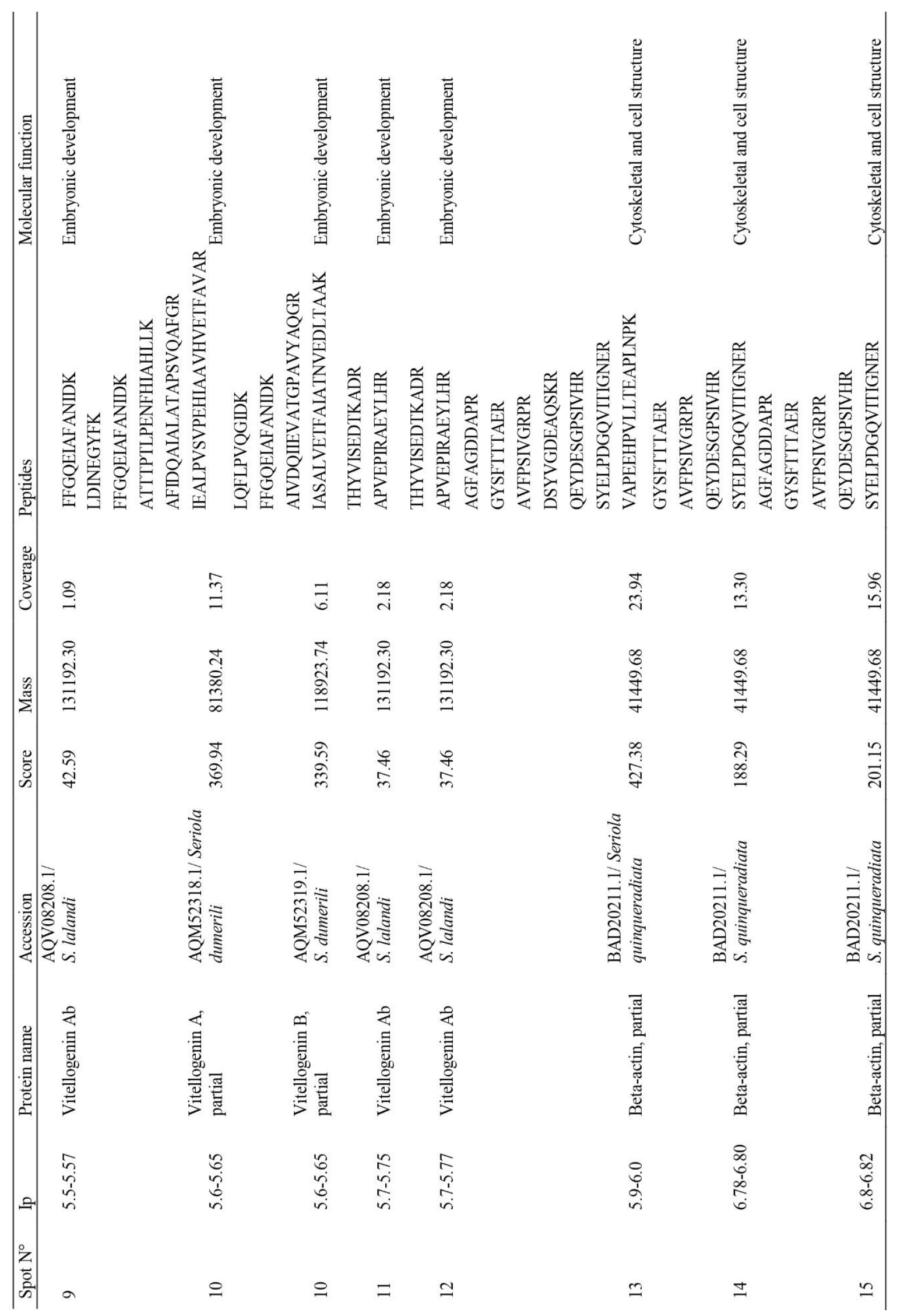


continuation

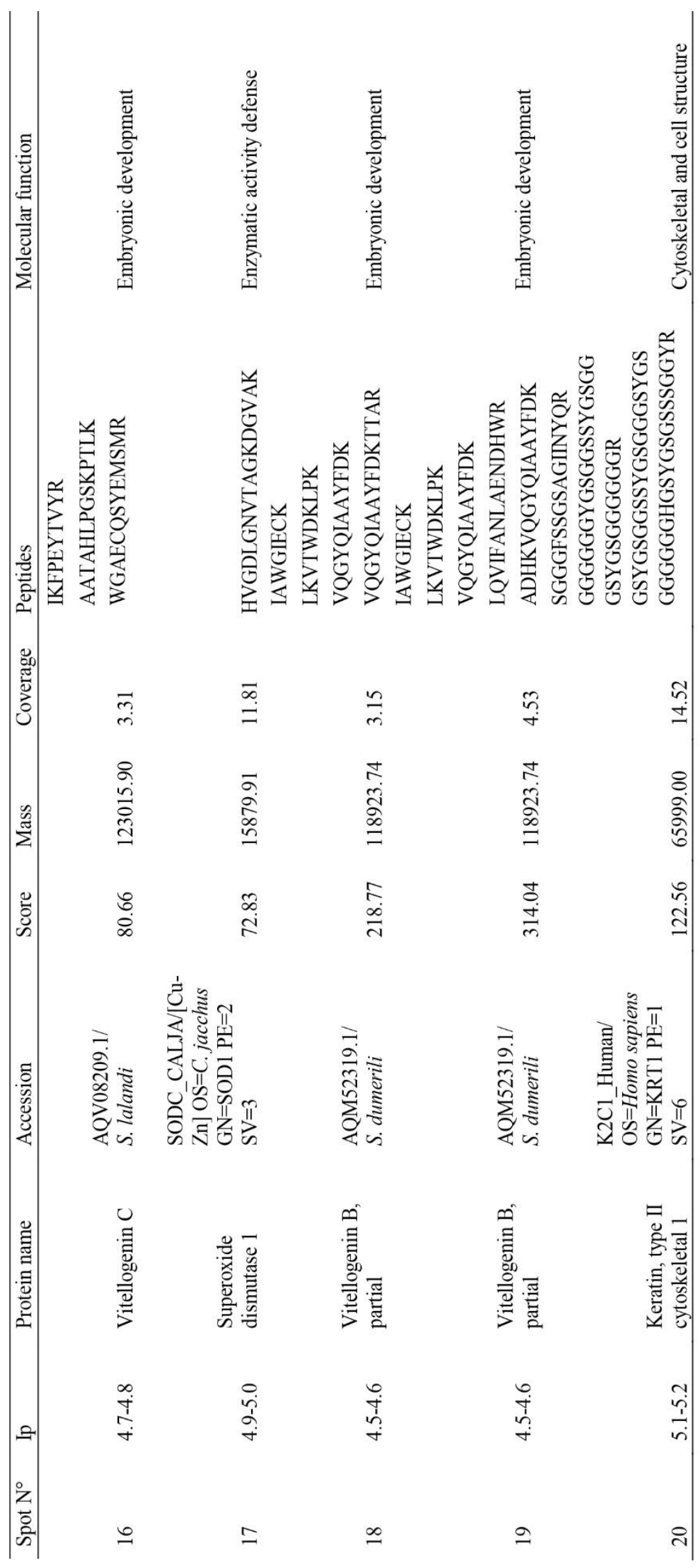


(Abe \& Chiba, 2004) (Table 1). It was found in Sparus aurata oocytes (Ziv et al., 2008) and Perca fluviatilis eggs (Castets et al., 2012). Another protein identified in our study and represented by three spots was the antioxidant enzyme SOD1, which was the first to identify this enzyme in eggs of this fish group. Recently, the presence of some enzymes involved in energy metabolism have been identified as suitable biomarkers to define the quality of fish larvae (Lahnsteiner \& Patarnello, 2004), and SOD1 is one of them. The study conducted by Valderrama-Díaz (2014) evaluating antioxidant enzymes SOD and catalase (CAT) in oocytes and embryos of Brycon amazonicus found that enzymatic antioxidant defense mechanisms increased their expression during embryonic development. Furthermore, they were the first line of defense against reactive oxygen species (ROS). The presence of oxidative stress in eggs or their parents caused by captivity could lead the fish to situations of anemia or opportunistic infections (Castillo-Hernández et al. (2020). Overexpression of this enzyme could be preventing damage by removing oxygen $\left(\mathrm{O}_{2}\right)$, hydrogen peroxide $\left(\mathrm{H}_{2} \mathrm{O}_{2}\right)$, and some metal ions, such as iron $(\mathrm{Fe})$, copper $(\mathrm{Cu})$, and zinc $(\mathrm{Zn})$, that can sequester and inhibit the uncontrolled action of $\mathrm{O}_{2}$ (Halliwell \& Gutteridge, 1999). The SOD1 protein was found in Salmo iridaeus (Aceto et al., 1994), D. rerio, and $S$. aurata oocytes (Ziv et al., 2008) and in Oryzias melastigma embryos (Dong et al., 2014) in the response of stress conditions.

Another kind of protein identified in this study and represented by two spots was peroxiredoxin, another protein associated with oxidative stress in fishes (Ziv et al., 2008; Castets et al., 2012; Yoshino et al., 2016). ROS, such as superoxide radicals, hydroxyl radicals, and $\mathrm{H}_{2} \mathrm{O}_{2}$ is formed during the reduction of dioxygen $\left(\mathrm{O}_{2}\right)$ in water. These species can damage proteins, lipids, and nucleic acids, so efficient antioxidant systems are required, including certain enzymes capable of degrading hydrogen peroxides, such as catalases, peroxidases, and peroxiredoxins (Díaz, 2003). The peroxidase and glutathione peroxidase (GPX) systems are the two main sets of oxidative stress response genes in chum salmon eggs (Yoshino et al., 2016). This same protein was also expressed in D. rerio and S. aurata oocytes (Ziv et al., 2008), and Perca fluviatilis eggs (Castets et al., 2012).

Another protein expressed in almaco jack eggs in this study was the proteasome subunit alpha type 1 -the proteins that make up the proteasome machinery (Baumeister et al., 1998). This machinery's function plays an essential role in the degradation of proteins in a wide range of cellular events. Eukaryotic cells have developed two mechanisms to perform many controlled proteolytic events - ubiquitination machinery and the proteasome. The collaborative action of these two machines is crucial for a variety of diverse processes that include cell cycle progression, development, apoptosis, signal transduction, antigen presentation, and gene expression regulation (Baumeister et al., 1998). This protein is a factor promoting fish oocyte maturation (Tokumoto, 1998; Chu et al., 2006) in response to situations of cellular stress, such as infections, sudden changes in temperature, or oxidative damage. Thus, these proteins are expressed to identify other poorly folded proteins and mark them for proteasomal degradation. This enzyme has also been identified in eggs of the species P. fluviatilis (Castets et al., 2012).

In conclusion, the results of this first experience of proteomic characterization of $S$. rivoliana fertilized eggs revealed some of the essential proteins required in forming an embryo and allowed us to identify antioxidant proteins associated with oxidative stress. This characterization will serve as a reference for future crops in captive conditions. The expression of these antioxidant proteins could represent early biomarkers of egg and larval quality in this species and the genus Seriola spp. These markers can be extremely important to avoid wasting efforts producing low-quality larvae in hatcheries.

\section{ACKNOWLEDGMENTS}

The authors would like to thank Hever Latisnere and Edison Barroso for their technical support. Javier Moch Martínez and Kampachi Farms for maintenance of the reproductive organisms and Milton Spanopoulos Zarco for providing fertilized eggs to perform this research; Diana Fischer for editorial services in English. Funding was provided by the Centro de Investigaciones Biológicas del Noroeste, SC (CIBNOR Project PPAC2017).

\section{REFERENCES}

Abe, S. \& Chiba, S. 2004. Seriola quinqueradiata cDN. UniprotKB database. [https://www.uniprot. org/uniprot/Q6L6Q2]. Reviewed: February 7, 2019.

Aceto, A., Amicarelli, F., Sacchetta, P., Dragani, B., Bucciarelli, T., Masciocco, L., Miranda, M. \& Di Ilio, C. 1994. Developmental aspects of detoxifying enzymes in fish (Salmo iridaeus). Free Radical Research, 21: 285-294.

Baumeister, W., Walz, J., Zühl, F. \& Seemüller, E. 1998. The proteasome: paradigm of a self-compartmentalizing protease. Cell, 92: 367-380. 
Bromage, N.R., Porter, M. \& Ryall, C. 2001. The environmental regulation of maturation in farmed finfish with special reference to the role of photoperiod and melatonin. Aquaculture 197: 63-98.

Bromage, N.R., Bruce, M., Basavaraya, N., Rana, K., Shields, R., Yong, C., Dye, J., Smith, P., Gillepsie, M. \& Gamble, J. 1994. Egg quality determinants in finfish: the role of overripening with special reference to the timing of stripping in the Atlantic halibut Hippoglossus hippoglossus. Journal of the World Aquaculture Society, 25: 13-21.

Byrne, B.M., Gruber, M. \& Gruber, A.B. 1989. The evolution of yolk proteins. Progress in Biophysics and Molecular Biology, 53: 33-69.

Carnevali, O., Mosconi, G., Cambi, A., Ridolfi, S., Zanuy, S. \& Polzonetti-Magni, A. 2001. Changes of lysosomal enzyme activities in sea bass (Dicentrarchus labrax) eggs and developing embryos. Aquaculture, 202: 249-256.

Castets, M.D., Schaerlinger, B., Silvestre, F., Gardeur, J.N., Dieu, M., Corbier, C., Kestemont, P. \& Fontaine, P. 2012. Combined analysis of Perca fluviatilis reproductive performance. Theriogenology, 78: 432442.

Castillo-Hernández, S.S., Rincón-Uribe, J.S. \& CastellanosDuarte, F.A. 2020. Estrés oxidativo en peces. Universidad Cooperativa de Colombia, (under review).

Cerdà, J., Maes, T., Bobe, J., Babin, P.J., Admon, A. \& Lubzens, E. 2007. Aplicación de la genómica funcional $\mathrm{y}$ proteómica en el estudio de la reproducción y calidad de los gametos de teleósteos. In: Martínez-Portela, P. \& Figueras-Huerta, A. (Coord.). Genética y genómica en Acuacultura. DiScript Preimpresión, S.L., Madrid, pp. 575-619.

Chu, S.L., Weng, C.F., Hsiao, C.D., Hwang, P.P., Chen, Y.C., Ho, J.M. \& Lee, S.J. 2006. Profile analysis of expressed sequence tags derived from the ovary of tilapia, Oreochromis mossambicus. Aquaculture, 251: 537-548.

Díaz, A. 2003. La estructura de las catalasas. REB, 22(2): 76-84. [https://www.yumpu.com/es/document/view 34569828/2003-2-la-estruc-/3] Reviewed: April 24, 2019.

Dong, S., Kang, M., Wu, X. \& Ye, T. 2014. Development of a promising fish model (Oryzias melastigma) for assessing multiple responses to stresses in the marine environment. BioMed Research International, 2014: 563131. doi: 10.1155/2014/563131

Fagotto, F. 1995. Regulation of yolk degradation, or how to make sleepy lysosomes. Journal of Cell Science, 108: 3645-3647.

Gopalakrishnan, V. 1985. Taxonomy and biology of tropical finfish for coastal aquaculture in the IndoPacific region. In: Stoner, A. \& Yáñez-Arancibia, A.
(Eds.). Fish community ecology in estuaries and coastal lagoons. Toward and ecosystem integration. Universidad Nacional Autónoma de México, Ciudad de México, pp. 615-628.

Halliwell, B. 1999. Free radicals, other reactive species, and disease. In: Halliwell, B. \& Gutteridge, J.M.C. (Eds.). Free radicals in biology and medicine. Oxford University Press, Oxford, pp. 617-783.

Heming, T.A. \& Buddington, R.K. 1988. Yolk absorption in embryonic and larval fishes. In: Hoar, W.S. \& Randall, D.J. (Eds.). Fish physiology. Elsevier, London, pp. 407-446

Jensen, O.N. 2004. Modification-specific proteomics: characterization of post-translational modifications by mass spectrometry. Current Opinion in Chemical Biology, 8: 33-41.

Jensen, O.N. 2006. Interpreting the protein language using proteomics. Nature reviews. Molecular and Cellular Biology, 7: 391-403.

Keyvanshokooh, S. \& Vaziri, B. 2008. Proteome analysis of Persian sturgeon (Acipenser persicus) ova. Animal Reproduction Science, 109(1-4): 287-297.

Kjørsvik, E., Mangor-Jensen, A. \& Homefjord, I. 1990. Egg quality in fishes. Advances in Marine Biology, 26: 71-113.

Knoll-Gellida, A., Yré, M., Gattegno, T., Forgue, J., Admon, A. \& Babin, P.J. 2006. Molecular phenotype of zebrafish ovarian follicle by serial analysis of gene expression and proteomic profiling, and comparison with the transcriptomes of other animals. BMC Genomics, 7: 46.

Lahnsteiner, F. \& Patarnello, P. 2004. Egg quality determination in the gilthead sea bream, Sparus aurata, with biochemical parameters. Aquaculture, 237: 443-459.

Lahnsteiner, F., Giménez, G. \& Estévez, A. 2008. Egg quality determination based on the shape of the lipid vesicle in common dentex, Dentex dentex. Aquaculture Research, 39: 144-149.

Link, V., Shevchenko, A. \& Heisenberg, C.P. 2006. Proteomics of early zebrafish embryos. BMC Developmental Biology, 6: 1.

National Center for Biotechnology Information (NCBI). 2017. [https://www.ncbi.nlm.nih.gov]. Reviewed: February 10, 2019.

Olin, T. \& Von Der Decken, A. 1990. Yolk proteins in salmon (Salmo salar) oocytes, eyed eggs, and alevins differing in viability. Canadian Journal of Zoology, 68(5): 895-900.

Palmblad, M., Henkel, C.V., Dirks, R.P., Meijer, A.H., Deelder, A.M. \& Spaink, H.P. 2013. Parallel deep 
transcriptome and proteome analysis of zebrafish larvae. BMC Research Notes, 6: 428.

Palomino, J., Herrera, G., Torres-Fuentes, J., Dettleff, P., Patel, A. \& Martínez, V. 2017. Assessment of cathepsin mRNA expression and enzymatic activity during early embryonic development in the yellowtail kingfish Seriola lalandi. Animal Reproduction Science, 180: 23-29.

Pousis, C., Mylonas, C.C., De Virgilio, C., Gadaleta, G., Santamaria, N., Passantino, L., Zupa, R., Papadaki, M., Fakriadis, I., Ferreri, R. \& Corrier, A. 2018. The observed oogenesis impairment in greater amberjack Seriola dumerili (Risso, 1810) reared in captivity is not related to an insufficient liver transcription or oocyte uptake of vitellogenin. Aquaculture Research, 49: 243252.

Rime, H., Guitton, N., Pineau, C., Bonnet, E., Bobe, J. \& Jalabert, B. 2004. Post-ovulatory ageing and egg quality: a proteomic analysis of rainbow trout coelomic fluid. Reproductive Biology and Endocrinology, 2: 26-35.

Roo, J., Fernández-Palacios, H., Schuchardt, D., Hernández-Cruz, C.M. \& Izquierdo, M.S. 2014. Influence of hormonal induction and broodstock feeding on longfin yellowtail Seriola rivoliana maturation, spawning quality and egg biochemical composition. Aquaculture Nutrition, 21(5): 614-624.

Serrano-Pinto, V., Vazquez-Boucard, C. \& VillarrealColmenares, H. 2003. Characterization of yolk proteins during ovary and egg development of mature female freshwater crayfish Cherax quadricarinatus. Physiology. Part A Molecular and Integrative Physiology, 134: 33-43.

Serrano-Pinto, V. Acosta, M., Luciano-Bazan., D, Hurtado-Sil, G., Ferreira-Batista, C., MartínezBarnetche, J. \& Lanz-Mendoza, H. 2010. Differential expression of proteins in the midgut of Anopheles albimanus infected with Plasmodium berghei. Insect Biochemistry and Molecular Biology, 40(10): 752758. doi: 10.1016/j.ibmb.2010.07.011

Received: 6 June 2019; Accepted: 12 June 2020
Sullivan, C.V., Chapman, R.W., Reading, J. \& Anderson, P.E. 2015. Transcriptomics of mRNA and egg quality in farmed fish: some recent developments and future directions. General and Comparative Endocrinology, 221: 23-30.

Tay, T.L., Lin, Q., Seow, T.K, Tan, K.H., Hew, C.L. \& Gong, Z. 2006. Proteomic analysis of protein profiles during early development of the zebrafish, Danio rerio. Proteomics, 6: 3176-3188.

Tokumoto, T. 1998. Nature and role of proteasomes in maturation of fish oocytes. International Review of Cytology, 186: 261-294.

Valderrama-Díaz, J.A. 2014. Determinación de la actividad catalasa (CAT) y superóxido dismutasa (SOD) en embriones de yamú (Brycon amazonicus) conservados a $-14^{\circ} \mathrm{C}$. Tesis de Licenciatura, Universidad de la Salle, Bogotá, 62 pp.

Viader-Guerrero, M. 2019. Influencia de la temperatura sobre el desarrollo larval temprano del jurel Seriola rivoliana. Tesis de Maestría, Centro de Investigaciones Biológicas del Noroeste, La Paz, 58 pp.

Williams, V.N., Reading, B.J., Hiramatsu, N., Amano, H., Glassbrook, N., Hara, A. \& Sullivan, C. V. 2014. Multiple vitellogenins and product yolk proteins in striped bass, Morone saxtilis: molecular characterization processing during oocyte growth and maturation. Fish Physiology and Biochemistry, 40: 395-415. doi: 10.1007/s10695-0139852-0

Yoshino, A., Polouliakh, N., Meguro, A., Takeuchi, M., Kawagoe, T. \& Mizuki, N. 2016. Chum salmon egg extracts induce upregulation of collagen type I and exert antioxidative effects on human dermal fibroblast cultures. Clinical Interventions in Aging, 29(11): 1159-1168. doi: 10.2147/CIA.S102092

Ziv, T., Gattegno, T., Chapovetsky, V., Wolf, H., Barnea, E., Lubzens, E. \& Admon, A. 2008. Comparative proteomics of the developing fish (zebrafish and gilthead seabream) oocytes. Comparative Biochemistry and Physiology - Part D, 3(1): 12-35. 